JOSING: Journal of Nursing and Health

Volume 1, Nomor 2, Juni 2021

e-ISSN: $2745-7877$

p-ISSN: 2746-0851

DOI: https://doi.org/10.31539/josing.v1i2.2332

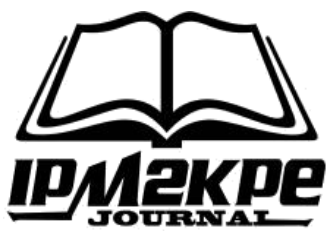

\title{
INTERVENTION OF NUMBERS PUZZLE AGAINST SHORT MEMORY MENTAL RETARDATED CHILDREN
}

\author{
Panzilion ${ }^{1}$, Padila ${ }^{2}$, Juli Andri ${ }^{3}$ \\ University of Muhammadiyah Bengkulu ${ }^{1,2,3}$ \\ padila@umb.ac.id ${ }^{2}$
}

\begin{abstract}
This study aims to see the effect of number puzzle intervention on increasing short memory in mentally disabled children at SDLBN 05 Bengkulu City. This study uses a quantitative approach using a Quasy Experiment design, one group pre-post test with a nonequivalent control group design. The results of the univariate analysis of the intervention ten samples 7 (30\%) with poor memory and $3(30 \%)$ good short memory samples and after being given number puzzle therapy, it was known that from 10 pieces, 8 (80\%) had a good memory and $2(20 \%)$ ) with less category. The paired test results showed that there was an effect of puzzle therapy on increasing short memory in SDLBN 05 Bengkulu City with a p-value of 0.000. In conclusion, there is an effect of number puzzle therapy intervention on increasing short memory of mentally disabled children in SDLBN 05 Bengkulu City.
\end{abstract}

Keywords: Short Memory, Number Puzzle, Mental Retardation

\section{INTRODUCTION}

Most mentally retarded (RM) children come to a pediatrician because of dysmorphisms, stunted development, or failure to fulfill their age-appropriate daily activities. The earliest signs are related to mental abilities or intelligence below average (Panzilion et al., 2020). In addition, most children with intellectual disabilities do not keep up with their peers and fail to comply with the norms expected for their age (Caesaria, 2019).

The World Health Organization WHO (2017) estimates that more than 450 million people experience mental disorders or mental retardation in the world. Currently, RM children become a burden of disease globally by $12 \%$ and are expected to increase by $15 \%$ by 2020 (Sharma et al., 2016). The potential of the Indonesian population with moderate to very severe mental disabilities based on the results of Riskesdas (2018) shows that the proportion of RM at the age of 5-17 years is $3.3 \%$. The ratio of children with disabilities of 5- 17 years by province, the highest region in Central Sulawesi with a rate of $7 \%$, and the lowest is West Sulawesi with a figure of $1.4 \%$. According to the Bengkulu Provincial Health Office (2017) data, people with disabilities from the age of 017 years are 1732 children, with 533 children with mental retardation or $31.93 \%$.

Mental retardation students have unique characteristics, namely learning by "parroting" (rote learning) rather than thinking processes (understanding and understanding). Besides being characterized by sub-normal intellectual function, RM is also accompanied by limitations in position; mental retardation is a disorder characterized by significant rules in academic aspects and adaptive behavior expressed in conceptual, social, and adaptive skills practice. The IDEA (Individual Disabilities Education Act) 
defines that RM generally has a level of intellectual ability in normal circumstances, adaptive behavior during its developmental period, which adversely affects children's educational performance and difficulties remembering, especially short-term memory (Dewi \& Budiarti, 2017).

The obstacles that mentally disabled children have in memory or memory abilities, concise memory abilities, so they experience limitations in remembering, mentally disabled children have low short memory abilities than normal children. In contrast, the extended memory abilities of mentally disabled children are no different from normal children if there is continuous repetition; short-term memory is a memory system that has limited capabilities and is involved in recalling information for a short period. Short-term memory will not be stored for long unless there is a continuous repetition process. To improve short-term memory, proper intervention is needed, one of which is the provision of number puzzle therapy (Baihaqi, 2016).

Playing puzzles can improve children's memory systems, especially short-term memory (short memory). By playing puzzles for school age, children can train accuracy, coordinate children's eye and hand movements (Panzilion et al., 2020). Therefore, without the child realizing that their fine motor skills continue to be trained and develop properly, children playing puzzles begin to learn to recognize shapes and play the puzzle so that it becomes a complete form. This game can be done in groups. When children play in groups, children can learn how to work together and adapt to their friends. This game can also make children independent. Children can be entertained, and playing puzzles by themselves can teach children to be independent individuals (Nurwita, 2019).

Based on a survey conducted in January 2020, 48 students were attending SDLBN 05 Kota Bengkulu. Of the number of students who are mentally disabled or mentally disabled, 21 male students and nine female students, mentally disabled or mentally disabled children have difficulty summarizing, especially in remembering short-term or short memory, so appropriate intervention is needed to increase the temporary memory, one of them is an example is the use of the therapy puzzle.

The strength of this study is that none of the previous studies examined numerical puzzle therapy on the improvement of short memory in mentally disabled children.

\section{RESEARCH METHOD}

This type of research is quantitative with a quasi-experimental design of one group pre-post test equivalent without control design. Samples were taken by random sampling, with the number of samples in this study were $10 \mathrm{RM}$ children with inclusion criteria, namely children who attended SDLBN 05 Kota Bengkulu, children with mental retardation in grades 4, 5, 6 who were willing to be respondents, followed until the end of the study.

To measure the short memory of school-age children using a digid forward questionnaire where there are numbers 1-9 with categories 1-7 less and 8-14 good, before the intervention the children were first measured short memory and then given 45 minutes of meeting interventions for 3 week 14 meetings, at the 14th meeting the children were measured the short memory again using the digid forward questionnaire. 


\section{RESULTS}

\section{Univariate Analysis}

Table. 1

Frequency Distribution of Short Memory among School Children before Being Given Numerical Puzzle Therapy

\begin{tabular}{ccc}
\hline $\begin{array}{c}\text { Short Memory } \\
\text { (Pre Therapy Numerical Puzzle) }\end{array}$ & Frekuensi & Persentase (\%) \\
\hline Less & 7 & 70 \\
Good & 3 & 30 \\
\hline Total & 10 & 100 \\
\hline
\end{tabular}

Based on table 1 it can be seen that before being given the numerical puzzle therapy of 10 children, there were 7 children (70\%) with less short memory and 3 children (3\%) experiencing good short memory in SDLBN 05 Bengkulu City.

Table. 2

Distribution of the Frequency of Short Memory among School-Age Children after Being Given Numerical Puzzle Therapy

\begin{tabular}{ccc}
\hline Short Memory & Frekuensi & Persentase (\%) \\
(Pre Therapy Numerical Puzzle) & 2 & 80 \\
Less & 8 & 20 \\
Good & 10 & 100 \\
\hline Total & &
\end{tabular}

Based on the table 2 after being given number puzzle therapy, it can be seen that out of 10 children $8(80 \%)$ with less short memory and 2 children (20\%) experienced good short memory in SDLBN 08 Bengkulu City.

\section{Bivariate Analysis}

Table. 3

The effect of increasing short memory before and after being given number puzzle therapy on school age children

\begin{tabular}{|c|c|c|c|c|c|}
\hline Variabel & Mean & $\mathrm{N}$ & $\begin{array}{c}\text { Std. } \\
\text { Deviation }\end{array}$ & $\mathrm{CI}$ & p-value \\
\hline $\begin{array}{c}\text { Short Memory Pre Therapy } \\
\text { Number Puzzle }\end{array}$ & 6.80 & \multirow{2}{*}{10} & 1.317 & -1.189 & \multirow{2}{*}{0.000} \\
\hline $\begin{array}{c}\text { Short Memory Post Therapy } \\
\text { Number Puzzle }\end{array}$ & 8.70 & & 1.337 & -2.611 & \\
\hline
\end{tabular}

Based on table 3 it is known that before the numerical puzzle therapy intervention was carried out, the mean value was (6.80) with a standard deviation (1.317), while after being given the intervention the mean value was (8.70) with a standard deviation (1.337). The $\mathrm{p}$ value before and after the numerical puzzle therapy intervention is 0.000 . It can be concluded that there is an effect after the numerical puzzle therapy intervention is given to the short memory of RM children in SDLBN 05 Bengkulu City. 


\section{DISCUSSION}

Univariate Analysis

Based on table 1 above, it can be seen that out of 10 children, there are 7 children (70\%) with less short memory and 3 children (3\%) experiencing good short memory in SDLBN 05 Bengkulu City. Respondents in the less category were related to question number 7 where the child had difficulty mentioning numbers more than 5 digid.

The number puzzle method is one of the media that is considered practical to solve memory problems. This game is a game of loading pairs with numbers and has many benefits, one of which is that it can improve the development of cognitive abilities, especially in children with mental retardation. Where this puzzle game is also a game that requires cognitive skills to solve problems. In addition, this type of puzzle can also help the learning process (Lin \& Dunphy, 2016).

Yuniati's research results (2018); Padila, (2019); Panzilion, (2020) regarding puzzles is also able to influence the fine motor development of preschool children. Based on table 2 above, it can be seen that out of 10 samples, 8 (80\%) with less short memory and 2 samples (20\%) experienced good short memory in SDLBN 05 Bengkulu City. Regarding questions 8 and 9 where the child cannot remember the number of digid forward with the number 7 digid.

This is supported by the difference in the score difference after giving playing puzzle therapy because when there is stimulation, the child's brain structure changes dramatically, the relationship between neurons increases, the glial cells that support neuron function increase, and blood capillaries that supply blood and oxygen to them. the brain becomes denser. The brain stimulates positive effects on brain structure and function, including increasing nerve support cells, and improving memory and multiple synapses (connections between nerve cells). Supported by the research of Melliana et al., (2018) After giving puzzle games from a total of 34 children, the middle interval value was 30.00, thus giving good puzzle games with the highest score of 24 and the lowest score of 25.

\section{Bivariate Analysis}

Based on table 3, it is known that before the numerical puzzle therapy intervention was carried out, the mean value was (6.80) with a standard deviation (1.317), while after being given the intervention the mean value was (8.70) with a standard deviation (1.337). The $\mathrm{p}$ value before and after the intervention was 0.000 , which was smaller than the $\mathrm{p}$ value of 0.005 , thus it could be concluded that there was an effect after being given the numerical puzzle therapy intervention on the short memory of RM children in SDLBN 05 Bengkulu City.

Playing for all children is a necessity, as well as for RM or mentally retarded children, by playing the learning process will be effective and more quickly captured for the child's cognitive as well as social development.

In line with Maghfuroh's (2018) research, it was found that there were differences before and after being given puzzle playing therapy with a mean difference of 4.6. After the statistical test, paired samples T-test got the $p$ value $(0.002)<\alpha 0.05$. So there is an effect of using the puzzle playing method for preschoolers before and after being given puzzle playing therapy. 
This is explained by the results of research by Melliana et al., (2019) suggesting that there is an effect of giving puzzle games in improving the fine motor skills of mentally retarded children, seen to be able to stimulate children's motivation to learn while playing and improve short-term memory in RM children.

In line with the results of Susanti \& Trianingsih (2017) research, states that playing puzzle therapy is effective for children's fine motor development, because it can learn about the texture and arrangement of shapes, and the child's fingers become flexible, so that their fine motor skills are more trained according to the child's developmental stages. based on age.

Reinforced by Sutinah's research (2019), the short memory ability of children with mild mental retardation before being given pzzle therapy with a very low category was $50 \%$, after therapy it became $22.7 \%$, meaning that there was an effect of playing puzzles on the short-term memory skills of children with mild mental retardation with statistical test results obtained p_value $=0.000(<0.05)$.

The results of research by Muloke et al., (2017) show that there is an effect of educational games (Puzzle) on cognitive development of children aged 5-6 years, there is a difference in the mean difference in cognitive development scores before and after therapy (puzzle) with the mean value before 13.50 and after 16.60.

In line with the research of Nurhalifah et al., (2020), the results of the analysis of word search puzzle media showed that on average there was an increase in children's short-term memory. The improvement of students' memory can be seen from the results of pre-cycle I observations (preliminary observations), cycle I and cycle II. initial observation learning $39 \%$, save $47 \%$ and recall $42 \%$, in cycle I learning $68 \%$, save $66 \%$ and recall $64 \%$, and after cycle II learning $90 \%$, save $91 \%$ and remember $86 \%$. This means that there is an increase in the child's short-term memory after cycle II.

In line with the research of Oktariani et al., (2018) the results of the two-sample test paired with Wilcoxon Matched Pairs with a 95\% confidence level $(\mathrm{p} \leq 0.05)$ obtained $\mathrm{p}=$ 0.000. With a value of $\mathrm{z}=-5.099$, it can be concluded that there is an effect of playing puzzle therapy on improving memory in children with mental retardation.

\section{CONCLUSION}

There is an effect of numerical puzzle therapy on increasing the short memory of school-age children in SDLBN 05 Bengkulu City.

\section{SUGGESTIONS}

It is hoped that in future studies to provide combination therapy in addition to number puzzles to improve memory / long-term memory in children with other special needs who experience memory problems with a longer time.

\section{REFERENCES}

Baihaqi, M. (2016). Pengantar Psikologi Kognitif. Bandung: PT. Refika Aditama

Caesaria, D., Febriyana, N., Suryawan, A., Setiawati, Y. (2019). Gambaran Umum Pola Asuh pada Anak RM di RSUD DR. Soetomo. Psychiatry Nursing Journal (Jurnal Keperawatan Jiwa). 1(2). 57-63. http://repository.unair.ac.id/107019/

Dewi, C., \& Budiarti, M. (2017). Analisis Kesulitan Belajar Siswa Mental Retardation di SDN Kedungputri 2 (Studi Kasus di SDN Kedungputri 2, Paron Kabupaten Ngawi). MUADDIB: Studi Kependidikan dan Keislaman, 7(2), 132-143. DOI: 10.24269/muaddib.v7i2.796 
Dinas Kesehatan Provinsi Bengkulu. (2017). Informasi Anak Dengan Retardasi Mental 2017. Dinkes Provinsi Bengkulu. Diakses dari http://www.Riskesdas.com

Lin, T. C., \& Dunphy, S. M. (2013). Using the Crossword Puzzle Exercise in Introductory Microeconomics to Accelerate Business Student Learning. Jurnal of Education of Business, 88(2), 88-93. DOI: 10.1080/08832323.2011.649312

Maghfuroh, L. (2018). Metode Bermain Puzzle Berpengaruh pada Perkembangan Motorik Halus Anak Usia Prasekolah. Jurnal Endurance, 3(1), 55-60. DOI: 10.22216/jen.v3i1.2488

Melliana, P. S., Widyantoro, W., \& Oktiawati, A. (2019). Permainan Puzzle Meningkatkan Kemampuan Motorik Halus Anak Tunagrahita Sedang Kelas 1-3 SDLB Negeri Slawi. Stikes Bhamada Slawi. Jurnal Ilmu dan Teknologi Kesehatan (E-Journal), 10(2). https://doi.org/10.36308/jik.v10i2.162

Muloke, I. C., Ismanto, A. Y., \& Bataha, Yolanda. (2017). Pengaruh Alat Permainan Edukatif (Puzzle) terhadap Perkembangan Kognitif Anak Usia 5-6 Tahun di Desa Linawan Kecamatan Pinolosian Kabupaten Bolaang Mongondow Selatan. Jurnal Keperawatan, $5(1)$ 1-6. https://ejournal.unsrat.ac.id/index.php/jkp/article/view/14718/14286

Nurhalifah, N., Lestari, N., \& Yusuf, M. (2020). Efektifitas Media Pembelajaran Word Search Puzzle dalam Meningkatkan Daya Ingat Siswa pada Materi Ekosistem Kelas VII di SMP Muhammadiyah Kupang Tahun Ajaran 2018/2019. Jurnal Biosains dan Edukasi, 2(1), 17-23. journal.unmuhkupang.ac.id/index.php/biosed/article/view/337/227

Nurwita, S. (2019). Pemanfaatan Media Puzzle dalam Mengembangkan Motorik Halus Anak di PAUD Aiza Kabupaten Kepahiang. Jurnal Pendidikan Tambusai, 3(4), 803-810. https://doi.org/10.31004/jptam.v2i4.285

Oktariani, N. P., Sulisnadewi, N. L. K., \& Kumarawati, N. L. A. (2018). Pengaruh Terapi Bermain Puzzle terhadap Memori pada Anak RM. Community of Publishing in $\begin{array}{lll}\text { Nursing (Coping), 6(2), 89-94. } & \end{array}$ https://ojs.unud.ac.id/index.php/coping/article/download/13924/31470

Padila, P., Andari, F, N., \& Andri, J. (2019). Hasil Skrining Perkembangan Anak Usia Toddler antara DDST dengan SDIDTK. Jurnal Keperawatan Silampari, 3(1), 244256. https://doi.org/https://doi.org/10.31539/jks.v3i1.809

Panzilion, P., Padila, P., Setyawati, A. D., Harsismanto, J., \& Sartika, A. (2020). Stimulation of Preschool Motor Development Through Brain Gym and Puzzle. JOSING: Journal of Nursing and Health, 1(1), 10-17. https://doi.org/https://doi.org/10.31539/josing.v1i1.1166

Panzilion, P., Padila, P., Tria, G., Amin, M., \& Andri, J. (2020). Perkembangan Motorik Prasekolah antara Intervensi Brain Gym dengan Puzzle. Jurnal Keperawatan Silampari, 3(2), 510-519. https://doi.org/https://doi.org/10.31539/jks.v3i2.1120

Riskesdas. (2018). Hasil Utama Riset Kesehatan Dasar. Kementrian Kesehatan Republik Indonesia, 1-100. https://doi.org/https://doi.org/10.1088/17518113/44/8/085201

Sharma, S., Raina, S. K., Bhardwaj, A. K., Chaudhary, S., Kashyap, V., \& Chander, V. (2016). Prevalence of Mental Retardation in Urban and Rural Populations of the Goiter Zone in Northwest India. Indian Journal of Public Health, 60(2), 131-137. DOI: 10.4103/0019-557X.184545 
Susanti, M. M., \& Trianingsih, Y. (2017). Efektivitas Terapi Bermain Play Dough dan Puzzle terhadap Tingkat Perkembangan Motorik Halus pada Anak Usia Dini di Paud Dahlia Godong. The Shine Cahaya Dunia Ners Jurnal 2(1), 17-28. https:// doi.org/ 10.35720/ tscners.v2i1.31

Sutinah, S. (2019). Terapi Bermain Puzzle Berpengaruh terhadap Kemampuan Memori Jangka Pendek Anak Tunagrahita/ Jurnal Endurance, 4(3), 630. DOI: $10.22216 /$ jen.v4i3.4385

WHO. (2017). Word health organization. Diakses dari http///:www.wordhealthorganisation.com

Yuniati, E. (2018). Puzzle Mempengaruhi Perkembangan Motorik Halus Anak Usia Prasekolah di TK At Taqwa Mekarsari Cimahi. Jurnal Kesehatan, 11(1), 36-47. https://doi.org/10.32763/juke.v11i1.85 